\title{
CLIP1 Gene
}

National Cancer Institute

\section{Source}

National Cancer Institute. CLIP1 Gene. NCI Thesaurus. Code C84464.

This gene plays a role in both endocytosis and mitosis. 